\title{
The World and Work of Brian Friel
}

\section{An interview with Richard Pine '}

What inspired you, what made you first think of writing a book about

Friel, and then re-edit, update, and expand it almost ten years later?

I realized that I wanted - needed - to write a book about Brian Friel ${ }^{2}$ while I was attending a performance of Translations (1980) at the Abbey in the early 1980s. I was not very familiar with the work of Brian Friel then - I knew about Philadelphia, Here I Come! (1964) and Aristocrats (1979) and The Freedom of the City (1973) as almost everyone did, as a matter of course - but I had read After Babel by George Steiner (1975), and during the performance I realized that parts of After Babel were being used in the text of Translations, the characters were actually speaking sentences from After Babel. I found this very exciting intellectually, but I also found that what the playwright was doing with Steiner's text and, as I later discovered with Heidegger also, was something which was emotionally exciting as well. All the books that I have written were written out of an inner need of my own to explore something in myself which is also present in the work, the subject of my book. This is particularly true of the book on Friel and that on Lawrence Durrell. 3 And in this case the initial momentum came from this experience which was a very real one for me at the time because I was exploring the difficulties of translation and the difficulties of communication, as part of my consultancy work with the Council of Europe on cultural development in a post-imperial society. My book was published in 1990, and therefore when Friel had written several more plays during the following eight years or so, it seemed necessary to produce a new edition which has a very substantial extra chapter on the more recent plays and a much more extensive Introduction. 4

1. Brian Friel does not give interviews any more, but he consented to the idea that an interview is conducted about his work with Richard Pine.

2. Richard Pine, Brian Friel and Ireland's Drama (London: Routledge, 1990).

3. Richard Pine, Lawrence Durrell: the Mindscape (London: Macmillan, 1994; new edition, Corfu: Durrell School of Corfu, 2003).

4. Richard Pine, The Diviner: the Art of Brian Friel (Dublin: University College Dublin Press, 1999).

The AnaChronisT (2003) 233-251 ISSN 1219-2589 
When the book originally came out Making History (1988), and Dancing at Lughnasa (1990) were still very new, and I did not really have enough time to give due attention to them, so they receive much more attention in the 1999 edition, along with the subsequent plays.

Did you introduce a new viewpoint as well, for instance the postcolonial critical approach?

Although the original edition addressed the postcolonial topic, the appearance of Homi K. Bhabha's The Location of Culture in 1994 gave me the encouragement I needed to look more discursively at this theme, and Bhabha's ideas about hybridity and the "gap," which is so important in Making History, were very persuasive in writing the new edition. Also, as I experienced the more recent (post1990) plays, I became more deeply conscious of the private music within those plays, and I addressed this in the final two parts of the "Music" section, "Plays of Beyond" and "Magic."

The back cover of the new edition says that you have written it with the full co-operation of the playwright himself. How would you characterize this co-operation?

It is well known that Brian Friel is very reluctant to give interviews or to assist would-be students of his work, and when I started writing the book I was quite certain that I would need to meet him and talk with him and get his confidence if I was going to really understand what was happening in his work. I approached Seamus Deane who is a very close associate of his, not least because of their involvement with the Field Day Company, and he recommended to Brian Friel that he should see me. Then I went to Derry where we met, and we had a very long meeting. And since that time I have been very lucky that Brian Friel is always very courteous and honest in answering questions that I may have for him. He has never, as far as I am aware, tried to conceal or hold back anything. I think that as the co-operation is a friendship now (and I would be happy to call it that) it has deepened very considerably over the years as we got to know each other much better and to trust each other, and I think we are very fond of each other on a personal level. On a professional level I have been very honoured to be asked to write the programme notes for three of his plays now, including the most recent at the Gate Theatre in March 2002, a two-part production - an adaptation of Chekhov's The Bear, and a very important original one-act called Afterplay. And besides Deane, another close associate of Friel, Seamus Heaney, 
wrote an endorsement which appears on both editions of the book, which means a great deal to me because it goes to the heart of my interest in Friel and accords with my personal style as a critic: he said that the book contributed "to an understanding of how Friel's plays transmit meaning within the acoustic of the Irish cultural and political scene" and that my "readings" of Friel "deepen the sense of [his] complexity and modernity."

The title of this second edition is The Diviner, which is also the title of one of his short stories. Why did you find it appropriate for your book?

In my book I give considerable attention to the characteristic of the diviner, the person who can look down into the ground and see what is hidden there. Seamus Heaney also speaks about this in relation to Friel, and it was the title I originally wanted for the first edition but the publishers of that edition, Routledge, simply refused to allow me to use that title. It is to me a most important thing that an artist looks at his environment and can see another environment which is its shadow image if you like, it is a buried image. Greeks believe for example that for every village there is an identical village down beneath the surface of the earth, somewhere towards the middle of the earth, and they would never think of the one real village on the surface without remembering the buried village, and there is a great deal running throughout Friel as there is throughout Chekhov of people digging within themselves for their buried selves and to me that seems to be most important. The picture of Friel by Bobbie Hanvey, which appears on the cover of my book and has been used in several other places too, seems to me absolutely symbolic of the diviner in that short story, an extraordinary, priestly figure looking down into a lake, and being able to tell what is there within. It is an extraordinary photograph of clairvoyance, literally.

\section{The main chapters of your book are "Private Conversation," "Public Address," "Politics," "Music." Three of these titles refer to themes and approaches primarily, but the fourth one, "Music," seems to introduce a different plane. Could you explain this choice?}

The original three sections were designed, first of all, to distinguish private conversation from public address, to use that very common cliché, to distinguish between the short stories and the radio plays on the one hand and the more open, political approach of the stage plays. It is in public address that Friel later becomes much more outspoken, and outwardspeaking about the matters that have been presented on the stage. The third section, "Politics," was intended to 
show that Friel, if you like militantly, moves with Field Day and Translations into an arena which is not merely public but is political, that it is trying to engage with governments - he says at one point "why should not writers rule the country"? The final section of the new edition, "Music," is there because it seems to me that Friel, partly because of his resignation from Field Day, partly or more so because of his moving as a writer into a very much more private sphere, is not writing so much nowadays about public and political matters, he is exploring once again the inner chambers of the heart and the imagination. And he is asking that we respect his privacy in this, and there seems to me to be a much stronger sense, in inverted commas, of "music" being able to reach or to open up areas where language fails. He says this at the end of Dancing at Lughnasa, and he says it in the programme note for his seventieth birthday: "Music can get to the uncharted areas where most of our lives are lived." And this musicality seems to me to be the overriding characteristic of what he is writing at the moment. In Wonderful Tennessee (1993), in Give Me Your Answer, Do! (1997), and in his new rewriting of Chekhov, in The Yalta Game (2002) and in Afterplay, the musicality of what he writes is very evident. It is not just that he writes musical prose, its important effect is the music which is transmitted, and transferred from the stage to the audience. It may also be the case that "music," as a powerful medium which, at the end of Lughnasa, takes over from language, is the medium needed by people in a postcolonial context where in a sense language has failed them and has failed itself. Friel himself has suggested this, most famously in the concluding lines, or "bars," of Lughnasa, that music can empower a "ritual," a "wordless ceremony" which supersedes language and puts us "in touch with some otherness." 5 He has said that "music can provide . . . another way of talking, a language without words. Because it is wordless it can hit straight and unmediated into the vein of deep emotion." ${ }^{6}$ So I mean that our modern society, which is more rightly called "post-imperial" if we are looking at it from the perspective of the Western European experience as a whole, has exhausted our traditional strategies of speaking to ourselves, and that some kind of "music" is necessary, even if only to give language a rest and an opportunity to reformulate itself, to find translations between its ancient cultures and rituals and the new

5. Brian Friel, Dancing at Lughnasa (London: Faber and Faber, 1990), p. 71.

6. Brian Friel, "Seven Notes for a Festival Programme," in Brian Friel: Essays, Diaries, Interviews 1964-1999, ed. Christopher Murray (London: Faber and Faber, 1999), p. 177. 
cultures and rituals that are shaping, and being shaped by, the world into which we appear to be entering. But all that is very tentative, of course.

The section "Music" concerns itself with images of the child, and child characters in Friel's drama. Do you think this element is unique in his work, or can you think of his deploying the child as part of the general importance of the child in Irish drama?

This may sound flippant, but all Irish dramatists, all Irish writers, perhaps all writers everywhere suffered from some kind of impaired childhood. I mean that in the sense that very very few people have what you could call an idyllic childhood and people who do not have it tend to set out to find a compensation for that in their lives and are always striving to replace the unhappiness or the neglect or whatever it was that impaired their childhood with something else: they become businessmen, politicians or racing drivers or something the like. Those who become writers, as Georges Simenon said, often write out of a sense of unhappiness. In Brian Friel's case the short story, the very short story The Child, which he refuses to allow to be reprinted, is very indicative of what may have been his own childhood insecurity. I do not for a moment suggest that he had a very distorted childhood, he speaks very fondly of musical evenings spent with his parents and his two sisters at the piano, and it was obviously not entirely a disturbed childhood. But I cannot believe that when he writes of children as he does in the case of the silent, what I would call an autistic, child in Give me Your Answer, Do! at the beginning and at the very end of the play, that he is not at least able to emphathize with that kind of experience, even if he is not drawing on his own experience. A very specific instance which he has talked about is the fishing expedition with his father, becoming an important question in Philadelphia, Here I Come!, a kind of experience which I suppose a lot of people would have shared in Ireland, because of the until recently prevailing difficulty of talking about emotions, talking about relationships, inhibitions which are there partly from the school system, partly from the religious environment. People do not open up and talk about things and, therefore, when an audience is presented in a play with an experience with which they can identify, even though they cannot talk about it, they go home very moved and it will strike chords which many people cannot talk about. It's something that is familiar to the Irish Catholic mindset, because it has to do with the "confessional" method of communicating and gaining some level of absolution from that silent experience or exorcising oneself from it. A further point that I would mention about this is that the nos- 
talgia play has its roots in the trying to get back inside childhood, inside the original "home." There was an English critic who said when he heard the words "when I cast my mind back to that summer" etc. at the opening of Dancing at Lughnasa 7 that his heart sank, as he thought it was going to be "yet another nostalgia play." It is possible that non-Irish audiences, let us say English audiences, would have less sympathy with this kind of harking back or casting one's mind back, which suggests that a vignette of some kind of heaven, some sunny summer's day is going to be the substance of the play. Friel, Tom Murphy, and Sebastian Barry are harking back in many of their plays, and we always have to remember that nostalgia literally means the pain of the homeward journey. And that painful experience of the homeward journey or the attempted homeward journey is what a lot of memory is about, it is a journey which asks the audience to accompany the characters in order to try and tease out some aspect of childhood, and of growing. In another, much wider sense the analogy can be made with postcolonial societies where the "old certainties" are no longer reliable, where the reaching back of our memory into the past is no longer sufficient to connect with the household gods or the communal home truths which command our affections and empower our daily lives and our political actions - in that sense, the need to "touch base," to undertake the homeward journey, is bedevilled by that inability to establish adequate lines of communication between son and father, pupil and teacher, servant and master, between our blank ignorance of today and the funds of wisdom that existed in illo tempore, and that can be very painful in situations where parent and child, or junior people and figures of authority, are at loggerheads - again, I address this rather extensively in the new Introduction to my book.

\section{Is growing up a seminal issue for Irish as opposed to English writers?}

The Bildungsroman or, as I call it in the book, Bildungsdrama is quite different depending on the context and the wider society in which one did the growing up - or of course failed to grow up. Again, Murphy would be very close to Friel in his intentions here. The Irish experience - again, I would stress the confessional aspect to society, which is so closely related to the "whisper-in-your-ear" of betrayal - is far removed from that of other societies, such as Britain or America, which have been infused with a different kind of religious awareness. It may be that it strikes much stronger chords with societies in which mystery and magic

7. Friel, Dancing at Lughnasa, p. 1. 
have a greater role, such as those studied by Victor Turner which I refer to quite extensively in my book. Of course, the problem of growing up in Irish society is one which is constantly being revisited by Irish writers both on and off the stage - in many ways it can be seen as parallel to, if not symptomatic of, the wider societal experience of growing a newly emergent state into adulthood, maturity and world stature; a frequent subject for debate in Irish schools for decades was: "That Emmet's epitaph can now be written" - in other words, that Ireland had taken her place among the nations of the world. And it's the haunting backdrop to Friel's early play The Mundy Scheme (1970). It remains a vitally important issue for the Irish writer.

\section{By far the internationally best known contemporary Irish playwright, Friel remains a very national author, in accordance with Yeats's one- time claim that great art and nationality are interdependent. The presence of national concerns in his work is fairly obvious, but what aspects of its form and technique qualify as unmistakably Irish?}

I think the most straightforward answer to that is that the traditional form of a kitchen is something which is explored over and over again. Of course there was a "kitchen-sink" phase in British drama in the 1950s and 60s, but there is a much bigger proportion of Irish plays just set in a household and usually in a kitchen. Again Tom Murphy would be a very obvious parallel to Friel in this respect. The play which has been regarded as the father of modern Irish drama is Friel's Philadelphia, and yet it did not entirely "break the mould" of Irish playwriting as it was still set in a kitchen. And although there were certain technical novelties, I do not think that they are as important as the fact that what Friel managed to do in that play was to set people in a kitchen and yet transcend the limitations which we had seen in many other plays. When we get to Translations, it is ostensibly someone's home, the home of the schoolmaster and his two sons, and yet it very obviously is not a home in the sense that most people would expect. There is no comfort in it, and there is in fact no focus, there is no hearth, not in any productions that I have seen. And in Lughnasa, again, you have got a household under threat - it is Kate who is trying to hold it together while all other forces seem to be pulling it apart. Living Quarters (1977) would be another example - the title is a terrible pun of course, it is not a home, it is something provided by the army for its officers to occupy, and yet, as long as they can remember, it has been their home - as for the three sisters in Chekhov's play. In other words, in a large number of his plays Friel has stuck to the traditional 
venue and forum of Irish drama, and yet he has been providing incisive commentaries, such as the fact that the place is not a home. In Lughnasa the whole home is threatened and eventually disintegrates, under the weight partly of modernization, and partly ostracization. I suppose the other thing which is invisible, quite distinct from the question of where he locates his plays, is of course speech. Friel's speech is quite unmistakably Irish. And yet, and this is partly responding to the question of his being an internationally well known author, and yet despite the fact that everyone is quite clearly Irish and is located in Ireland, these plays travel extremely well: you would know that from your experience of Hungarian productions of Brian Friel. ${ }^{8}$ Molly Sweeney (1994) is currently in the repertory of the Maly Theatre of St. Petersburg. Translations, because of its appeal to any postcolonial society, has played in a vast range of countries including Estonia, Catalonia, Nigeria. This is partly because the emotions which have been expressed find a resonance within the audiences in other countries, and partly because there is an international vogue for the Irish theatre, and it is partly, I think, because the sheer music through the voices of his characters is so emotionally appealing to audiences everywhere.

\section{What are the most important connections of his dramatic work with international theatre, classical and contemporary?}

Apart from what I have just said about postcolonial themes, I am not sure that there are many playwrights with whom his work connects, and I cannot think of many playwrights with whom you can compare his work. I would be very tempted to say that he is one of the greatest living playwrights: the reason for that is because so few people elsewhere are writing what I would call challenging drama. Athol Fugard and Wole Soyinka would be cognate authors in this respect, and perhaps because they are close to the same postcolonial experience, and to an African reality that accords somewhat to the Irish reality. There are few plays on in the Broadway theatres apart from musicals, or resurrections of old stuff, and no one in England is writing much - Tom Stoppard, for instance, has been relatively silent for a time. Stoppard, I think, is a wonderful writer but he is not quite in the same league as Friel, and if British theatre is applauded because of facile writers like Alan Ayckbourn, then it is a theatre in serious trouble. I think the reason that Friel's importance has not been recognized as widely as it should

8. So far Dancing at Lughnasa, Translations, Philadelphia, Here I Come! and The Communication Cord have been produced by Hungarian theatres. 
is because, in Britain obviously, with a much larger market, someone like Stoppard has a success immediately, and because of that success he becomes internationally well known, whereas it took a very long time for Friel to become known, accepted, recognized, and celebrated outside Ireland, and it is a difficulty which Tom Murphy is still experiencing in getting his plays outside the British Isles.

The Yalta Game is another adaptation of Chekhov after his 1998 version of Uncle Vanya, preceded by Three Sisters in 1981. Why do you think Chekhov is so important for Friel that he comes back to him the third time?

Friel's new version of The Bear and his own "Russian" play called Afterplay are also works that represent this coming back. The basic reason is that Friel empathises very deeply with, let us call it, the spirit, and the themes of Chekhov and Turgenev which are paradigmatic of the Russian soul or spirit. People who spend their entire lives waiting, hoping for something, people who are quite convinced that real life is elsewhere - these I think Friel recognizes as being also very Irish themes, because of the nineteenth-century experiences of emancipation and of famine, and he loves reading the Russian writers. I think it is very easy for him, comes naturally to him, to write versions of Russian plays and stories, and I think it has been quite an exciting thing for him to write Afterplay, which consists of two characters, one of whom is Sonya Serebrjakova from Uncle Vanya, and the other is Andrej Prozorov from Three Sisters, because of the challenge he set himself of "marrying" them into some kind of intimacy which would illuminate both precedent plays while creating new lives in a new play.

What are Friel's main thematic preoccupations?

Questioning the concept of home. He said to me that he resists the concept of community, and is not sure that he can accept the idea of home, and that is a massive preoccupation. Within that preoccupation is the whole question of what constitutes the home. Obviously, it means family. Both within family and outside, in relation to the rest of the society is the question of trust, the question of understanding, the question of faith, not only faith in the religious sense but faith in oneself, faith in others. These obsessions come out for example in Give Me Your Answer, Do!, in which two marriages are under very great tension, and a home certainly under very severe threat of collapse (I mean emotional collapse), and while the whole idea of faith, trust and understanding is being explored in most intimate and painful detail, there is also this idea of the miracle 
and magic, which is there in Wonderful Tennessee together with storytelling which Friel described as a "Canterbury Tales" type of play, where reaching out for the invisible island, the Island of Magic, has the central character Terry so excited, and the rest of them revolving around him telling their tales. The idea, and the whole question of storytelling which I think is absolutely fundamental to the Irish theatre, is something which I should add to what I said about the form and technique of Irish theatre being present in Friel's plays. Well, not just storytelling in the sense of spinning out a yarn, but reaching the point at which, during a play, during one's own life, a story has to be told, which releases a secret and the telling of the secret releases some emotional angst. To move briefly away from Friel, the most telling, the most piercing example of that in my experience, and I was lucky to see it with Siobhan McKenna in the role, was Tom Murphy's Bailegangaire (1984).

Why is getting nearer to telling the truth through his characters so important for Friel?

Someone has to tell a story or admit to having told an untruth. It is going all the way through Molly Sweeney, the three stories being told there - three interrelated stories - and it is in Afterplay too, where Sonya and Andrey have to keep apologizing and admitting that what they just said is not quite true, it is a little bit of fiction. So they are getting nearer and nearer to telling the truth all the time, and I think that is a very strong element running through Friel's plays. Going right back to say Philadelphia, and to The Loves of Cass McGuire (1967) a play I have not mentioned yet. Establishing a truth is like providing oneself with a benchmark which ought to have been there for one from the outset, but which wasn't there: if we can find it, or a satisfactory substitute, even at this late stage, it will assist us in completing the essential journey which began with this "outset" - i.e. the leaving home which has to be fulfilled by the journey back home, the nostalgia.

The portrayal of failure and loss are often mentioned in comments on Friel's plays, yet they do not lack comic scenes or characters. How do these two features go together?

A case of that of course would be The Gentle Island (1971) which is a terribly serious play about the collapse of a community and the stories told within it, but it has some extremely funny lines in it. I think the point is that the telling of a truth is much more piercing and effective when tears are accompanied by laugh- 
ter. At the end of the first edition of my book I said something which I actually brought to the front of the second edition, and that is my own view that ultimate freedom equals a self-deriding laughter, that is something in which I still believe - that the ultimate freedom is to go wherever I go at my own risk and at my own pace, and under my own direction, the Greek word for freedom, "eleutheria" means literally, etymologically, to go where I will. One's inclination for selfdestruction, which we see in Fox in Crystal and Fox (1970), is that kind of freedom. I think a black comedy is something that Friel would see happening within a great deal of his own work. Look at Teddy in Faith Healer (1979) and his commentary on the world of make-believe, with which he has been associated all his life. And look at the extraordinarily funny ways in which he comments on that.

\section{Which of Friel's plays mark artistic turning points in the development of his work?}

I already mentioned Philadelphia. I wouldn't say just an artistic turn, because I think that what happens in a play in terms of themes, and the way the author deals with them in terms of artistic technique, are interrelated. I would say quite simply that it is the major plays, and I would list those as Philadelphia, The Freedom of the City, then we move on to that extraordinary two-year period where he had Faith Healer, Aristocrats, and Translations, from 1979 to 1980. And those two years or so saw Friel's work moving onto a plane immeasurably higher than it had been before. Then, as we know, there was an extraordinary silence from 1982 to 1988, and that Making History has been put down as not a great play is I think due to the fact that it did not have a very good first production. It had a quite fantastic production in the late 1990s at the Peacock Theatre with Gerard McSorley as Hugh, and I think that production restored the play's reputation as a very important turning point. Obviously, so was Dancing at Lughnasa with its openly autobiographical stance, although I do not give quite as much reverence or admiration to that play as most people do. Then we move on to Molly Sweeney, and here I find myself absolutely in awe of what he achieved in that play. Friel himself, jokingly, said that it was like Faith Healer but I do not see that there is any real connection here, because the structure of the later play is quite different. Instead of the monologues of three characters you have monologues which are interspersed so effectively in the course of the play, that it is almost as if, but not quite, that they were meeting, and exchanging on stage. I think it is his most transparent play, his most beautiful play, and I 
think when the time comes to take a look at his entire output, Molly Sweeney will rank as one of the few best plays by Brian Friel. As I say, "but not quite" that nearness without touching is so potent in emphasizing how very distant they are from each other in terms of being able to understand or even cherish one another.
How far, in your view, did the Field Day connection, in my under- standing Friel's taking part in Northern Irish cultural politics, enrich his dramatic art; would it have, perhaps, taken a different route with- out this connection? What is Friel's "road not taken"?

In a sense I do not think Field Day enriched his dramatic art, it diverted his dramatic art into the service of politics, cultural politics perhaps, but politics nonetheless, and Field Day is not only a company producing and travelling their plays, but is a publishing house in which Friel took enormous personal interest, and huge personal commitment travelling frequently from his home into Derry to do office work. Field Day was a very necessary interruption to the way his work was going. What we have seen in the last, say, ten years is the direction, in other words the road not taken then, the road he is now taking with Lughnasa, Wonderful Tennessee, Molly Sweeney. In other words, attending to the inner man, the inner anxiety, the inner strength and weaknesses rather than, let us call it doing military service in the cause of his, in inverted commas, "community," an extremely dangerous term to use but shorthand for what one would understand as an intellectual response to politics in the North of Ireland in the company of people such as John Hume, the politician, and Seamus Deane the intellectual - some people say the ideologue - and Seamus Heaney the poet, and Stephen Rea on the stage side. In another sense, there is always a "road not taken," in that the chosen road, or the road one is compelled to take, prevents one from travelling other roads. In terms of homecoming, the chosen road is the road towards self-discovery, and if that road proves to be the wrong road, then of course there are other possible roads which one may regret not having taken. In Friel's case, the world and his wife perceive Lughnasa as the right road, the road of homecoming, and I don't argue with that; Translations, too, as it has been described as "a national epic," has a sense of bringing both the playwright and his "community" home to a certain set of truths, a point of arrival. But at a deeper level I think we can see that Friel has "come home" in much more profound ways - especially in the sense that Give me Your Answer, Do! is an equally autobiographical play, not about nostalgia but about hindsight - the 
"reckoning" of a seventy-year-old writer. And in Molly Sweeney - I don't apologise for coming back to the excellence of that play - there is a very definite sense of achievement which says, to me at least, that a homecoming has taken place in the locus that is of most concern to the writer - his own imagination and its connection with the world, both the intimate world and the more public world. So I would say that if Friel had continued producing plays in the "Field Day formula" there might well have been a "road not taken," but the road taken since Field Day has represented a much more satisfying route in the sense that the playwright has found a more effective way home to that personal hearth and a new way of communicating with an audience which is a new kind of "community."

\section{Would you call Friel an experimental playwright? Which plays qualify as most experimental in the Friel canon?}

I do not think he is very experimental, and much less so today than in the earlier plays, when he was still finding his way in the business of stagecraft, because today he is not interested in anything other than getting the voices across from the stage to the audience. And I do not think there is a single play by Friel which is totally original in any experimental way, even in Philadelphia, in the Gar divided into Private, and Public: there are instances of previous playwrights dividing a character in one way or another. How he does it is what makes the work so fascinating, by the strategy that he uses which is expressed in the stage directions in front of the play. If I may digress, the writer who has taken what I referred to earlier as the Russian themes of waiting, hope deferred, wasteland etc., and made them Irish and has done it in a very experimental way was, of course, Samuel Beckett. Athough I understood when I first met Friel that he really did not have much interest in Beckett, he was not terribly excited by Beckett, I found him more recently referring to Beckett, and if he does that there is perhaps some excitement derived from Beckett. Maybe it is Beckett who does hurry forward in a very advanced way some of those what I called "Russian" themes that are so important to Friel.

You call Molly Sweeney a "risky" play in your book. In what sense is it risky? Does it, perhaps, share an aspect of Beckett's late theatre, in that it affects the nerves of the audience, rather than their intellect?

Obviously one would think that there might be some link with Beckett, but it is not that at all. It is the fact that there is such emotional honesty, such transpar- 
ency in the play. I think it is extremely demanding on the three characters, on the three actors, it is extremely demanding if you believe those actors just actually are those three characters, it is extremely risky for them to be coming to us in the same way as Faith Healer, and telling us their stories. And it is terribly risky for the audience because there are such huge questions being raised which must make people in the audience look into their own hearts and be very disturbed by what they find there - questions about the accuracy of vision, of memory, the ability to express oneself clearly, to understand what another is saying, to appreciate their standpoint and their perspective.

\section{Memory scenes have such a marked presence in Friel's drama: is this phenomenon related to his interest in the importance of the past as an author from Northern Ireland, and the meaning of the past for various individuals?}

Although the North has obviously had a huge presence in his writing life and in his writing consciousness, I think that Friel is just doing what anybody would do who is fascinated with the past, with that business of trying to make the journey home. It is not a Northern fascination, just a human one, which is more evident in Ireland, a country for which the past is so problematic. The whole question of how the Irish came to be a dominated people, and how they began to deal with their freedom when they got it. Of course this is the subject of The Mundy Scheme, a play that has only been produced once and I should love to see.

Can you identify character types in Friel's work, who keep on returning in different guises? What establishes the importance of his outsiders, and commentators, for instance?

The fact that in most of his plays there is someone called O'Donnell, it is the O'Donnell family, and they are always living in Ballybeg. In my book I refer to a piece that he wrote, "A Fair Day at Glenties." Glenties is the town in the background of Lughnasa, his mother's town. And I say that these are the archetypal people who make up a whole microcosm, which of course is very Chekhovian too. And they are the people who keep cropping up, he lists them and they are all there in his plays. Let us call them an organic group of people, otherwise known by that awful word "family." When I say "awful” I do share with so many people a fear of the term "family," it is something that when I am talking to Brendan Kennelly for example we revert to again and again, this problem of intimate blood relations within that other four letter word "home." The outsiders and 
commentators are part of his experimentation if you like, each of them coming from some theoretical source, like Dodds, the sociologist in The Freedom of the City, or Sir in Living Quarters. These are devices, experiments again, but I do not think the plays that include them are more important than the plays that do not have them.

\section{The books and articles about Friel's art so far would make a small lib- rary. Do you notice some main directions in this growing bulk of the "Friel industry" as one might call it?}

Apart from the fact that people write books on Friel to promote their career, I think people are attracted to his work for two reasons, which may seem contradictory. One is the transparency that I already mentioned. When you pick up the copy of a play, you hold a whole world in your hand. And the contradictory thing is the difficulty of actually trying to describe it, it is a tremendous challenge, as I say it is partly what drew me to Friel in the first place. Most people who have written about Friel have a very strong reason, inner or personal reason for doing so. On the other hand, one wonders whether it is really justifiable to keep on producing books which in many ways reproduce the same material, I am thinking particularly of volumes of essays rather than monographs. I do not think that there are many main directions, not many people have tried to follow my sense of direction in looking at the spiritual side of Friel's work, the emotional side, the depth of that work. There has been more written about him from the political side and then of course there was a book quite recently, the one by F. C. McGrath about Friel as a postcolonial writer, 9 which is typical of so many academics' work who pick a subject to try and fit it into a thesis rather than trying to make a thesis out of the subject. I have never been persuaded by any kind of -isms, all I know is how I personally describe a subject that I am passionately interested in, and if that fits in with something someone else has written about some other writer, and it can be conveniently labelled with an -ism, then that is fine by me. I had recently a case of it in relation to my work on Lawrence Durrell, where somebody wrote about Durrell's Avignon Quintet (1974) with such a weight of ideological luggage that he succeeded in completely reversing my argument and still managed to quote me with approval; it is very frustrating to find this happening but it is entirely due to the way in which literature is taught nowadays in universities, that theory is more

9. F. C. McGrath, Brian Friel's (Post)colonial Drama: Language, Illusion and Politics. Reviewed by Richard Pine, Irish University Review 30.2 (Autumn/Winter 2000) 373-376. 
important than the plays which are taken to be illustrative of theory. So as far as the "Friel industry" is concerned, I hope it stays immune as far as possible from that kind of treatment because it is not the sort of attention which Friel deserves.

Philadelphia, an allegedly early masterpiece of Friel is strangely downgraded in McGrath's post-colonial study of Friel, while The Loves of Cass McGuire is highly thought of and is given a very substantial subchapter. How do you see this unusual repositioning of the two works? I also wonder if you have a similar appreciation for a less known play of the author.

There are plays McGrath simply ignores completely, because they do not fit in with his thesis. I felt that although Wonderful Tennessee is not in the front line of Friel's plays, it did not deserve, nor did Give Me Your Answer, Do!, quite the rejection which it got from the critics and which I think seriously disappointed Friel himself. Give Me Your answer, Do! is autobiographical again, and I think the critics got that all wrong. The essence of that play is faith, understanding, communication, and self-regard, and of course, we can quite rightly say it depicts a writer approaching a certain landmark in his life, the age of 70 , who wants to find out if his work is of any value, meaning, and significance. That is a perfectly reasonable inference to draw and, again, it is a play which has not yet found its right niche. I have already mentioned The Mundy Scheme as being a play I suppose out of just curiosity that I would like to see. It might need a little bit of rewriting because it is very much of its time and place, but I think it is so relevant. Beginning with the words "Ladies and Gentlemen, what happens to an emerging country when it has emerged?" ${ }^{\circ}$ which of course is the question mark standing over the entire literature on the issue of postcolonialism.

What were the most memorable Friel productions that you have seen in or outside Ireland?

I have mentioned the Translations production which sparked off my entire interest in Friel's work. The premiere of Dancing at Lughnasa at the Abbey in 1990, the premiere of Molly Sweeney at the Gate in 1994, were immensely gripping, exciting, challenging and, of course, Donal McCann in Faith Healer during an Abbey revival in the mid-1980s. A production of Aristocrats some time in the late mid-1990s with Sean McGinley and Frank McCusker was very exciting. To

10. Brian Friel, The Mundy Scheme (New York: Farrar Straus, 1970), p. 6. 
come to a personal thing, I saw a student production of Translations in Montgomery, Alabama, in which the director had the very interesting device which no one had thought of before, of having Owen speaking in an Irish accent when he spoke to his own people and an English accent when he spoke to the English soldiers. And I told Friel about this, and I think this is why in Making History he specifically says it in the stage directions that Hugh is to speak in a Tyrone accent when talking to his own people and in an English accent when talking to Mabel, his wife, and Mary, her sister. I am very pleased, indeed, if I did have any partial responsibility for that. The most gripping effect when you witness any Friel play is that it appears that he is directly addressing you, and he is engaging your emotional response, he is demanding an emotional response, and he is getting it very easily because he is almost picking you up by the collar, and dragging you on the stage. It is that immediate effect that makes you realize he wrote the play for you. And that is what I find extremely moving, emotionally speaking, and also amazingly challenging, stimulating, and obviously very difficult as the emotional charge is like being put in the emotional chair and having fifteen million volts put through you, that is the highest point available to you in a Friel play, and Molly Sweeney is probably the play that had that effect on me most.

What is Friel's relationship with the younger Irish playwrights? Do they respond to each other in any meaningful way? Can you see developments in Irish drama that open new paths leading away from the Frielian achievement?

I called Friel the Irish Chekhov - I was astonished a couple of years ago to find someone writing in the English Sunday Times "which is the new Irish Chekhov, Conor McPherson or Martin McDonagh"? ${ }^{11}$ Now I do not want to talk very much about those playwrights except to say that I feel far too much adulation has been directed at them, for far too little in terms of artistic quality. I cannot see any justification at all for writing of people who are so young and untested in many ways, to be regarded as anywhere near the work of Chekhov, or anywhere near the work of the man who has been called the Irish Chekhov - Brian Friel. The premiere of The Yalta Game - Friel's version of Chekhov's short story "Lady with Lapdog” - was presented in tandem with new plays by Conor McPherson and Neil Jordan; after their plays, and after the interval, the audience was presented with the Friel work, and there was a palpable sense of relief that here was a work of real theatricality -

11. Sunday Times, 12 July 1998. 
and I intend that oxymoron, of real makebelieve - a work so well written, so well conceived, that the other presentations were in a quite definitely lesser league. I don't mean to disparage those other writers, merely to insist that there is very little "competition" for the laureate position among the newer writers. I do not think that Friel is terribly interested in anybody else's work, I am sure he has read and he may have seen some of McPherson, or McDonagh, or Marina Carr's work, or perhaps Sebastian Barry's. What I do worry about is that I see these younger writers, with few exceptions - and Carr and Barry would be two of these exceptions - that the writing is not of great quality. Carr is a very poetic writer, and I enjoy her work very much, but what I call it is "the reinvention of the wheel," we are continually getting the same themes, related to the rural experience, the rural-urban divide, loneliness, faith, and mystery - I write about this in the Conclusion of my book. One young writer said that he had written a play which is the first one to have ever depicted young people going mad in the Irish countryside. He is writing out of a very high level of ignorance. He is not aware of Tom Murphy's early work, he is not aware of Philadelphia, he is not aware of M. J. Molloy's The Wood of the Whispering (1953). There is an extraordinary arrogance in the ability of a young playwright to think that he is writing the most original plays that have ever been written, and on subjects which have never been addressed before. I am afraid "what goes round comes round," and I would like to see much more new work being done on themes which are not necessarily Irish themes. There was great hope back in the 1980s for the work of Paul Mercier. I went to see a couple of his plays because I was led to believe that they were about the urban situation, and the working classes, and that at last we were getting plays which would address this section of the population - like Heno Magee's Hatchet (1972) or Peter Sheridan's and Jean Doyle's Shades of the Jelly Woman. And I found that they were all about middle class suburbia and about football teams. This to me is a waste of energy. A middle aged playwright I have not mentioned so far, Frank McGuinness, is someone with whom Friel does have a relationship in the sense that Frank directed the revival of The Gentle Island at the Peacock back in the early or mid 1980s, and there is a certain amount of, I believe, warmth of affection there. Certainly it is not just one-sided, Frank McGuinness acknowledges that seeing Faith Healer was the experience which enabled him to become a playwright, it gave him the courage to do that, and that in itself is an extraordinary achievement. And I think Friel likes the work of Frank McGuinness. After all, it was Frank who adapted Dancing at Lughnasa for the film screenplay - very sensitively, I thought. It is not from a Frielean perspective that I say this, but I am just very disappointed by the fact that Irish 
drama does not seem to have a development. The starting-off point is the same all the time, because of this awful urge to go back and examine origins, so you are always standing and waiting at the same bus-stop. You never actually let the bus take you to another country - tomorrow you will be back standing at the same bus-stop, wondering if the same bus will come.

\section{Do you think Friel will become, or is already a classic? What makes him one according to your understanding the word?}

Yes, in the sense that he is one of the absolutely top writers of plays in the English language in the world today. What makes him a classic is that he has universal appeal, because he writes hugely compelling work and because of the sheer quality of the language that he uses. It is of course Irish, it is not an inflection of Irish, it is Irish through and through, which of course immediately makes people realize that it is not standard English playwriting, but the quality of it is something which has gained him universal recognition. As he himself has made clear, writing about Ireland in the English language is an alien experience with which one cannot be comfortable until one feels at home in the "new" language, until one has made it "one's own" - and while that may be an arduous and painful journey for the writer, it is an extraordinarily fruitful and rewarding experience for the reader or listener who is meeting an extremely expressive and beautiful form of "English" which is lyrical, or pointed, or abrasive or beguiling by turns, but which has, above all, a strangeness about it that is sometimes mocking, sometimes appealing, sometimes confessional, but comes to you in an oblique voice that should be familiar and should sound like one's own, but doesn't - and this is an attraction that one cannot explain - that's why we keep going back to it.

Which of his work would you like to write about again, because it still mystifies you even after having analyzed it in your book?

All of it. That is the answer, all of it.

Mária Kurdi 